\title{
Death By A Thousand Cuts: The Rule Against Perpetuities
}

\author{
Angela M. Vallario*
}

\section{Introduction}

Much too familiar to us all is Professor John Chipman Gray's theorem on the Rule Against Perpetuities (the Rule) that no interest is good unless it vests or fails within a life in being plus 21 years.' However, a recent trend has begun among jurisdictions to statutorily abolish the Rule for contingent interests in trusts with private beneficiaries. Currently, seven jurisdictions: Maryland, ${ }^{2}$ Illinois, ${ }^{3}$ Alaska, ${ }^{4}$ Delaware, ${ }^{5}$ South Dakota, ${ }^{6}$ Wisconsin ${ }^{7}$ and Idaho ${ }^{8}$ have abolished the Rule Against Perpetuities. The abolishment of the Rule Against Perpetuities encourages settlors to create contingent interests in trusts that will last forever. These trusts are sometimes referred to as "dynasty" trusts."

The legislation provides wealthy settlors with transfer tax advantages and allows jurisdictions to remain competitive in the trust capital business. ${ }^{10}$ The abolishment legislation at first glance appears advantageous because it has transfer tax advantages for wealthy settlors, yet the ability of settlors to exercise dead hand control could have devastating affects on trust beneficiaries and the community at large. Dead hand control interferes with the marketability of trust assets and perpetuates the concentration of wealth."

This article suggests the policy and social justifications against dead hand control far outweigh transfer tax advantages provided to wealthy settlors and the potential revenue expected to be generated by the abolishment legislation. The abolishment legislation may be readily adopted by other jurisdictions in light of the legislatures' failure to recognize the consequences of unlimited dead hand control.

This article recognizes that the Rule is complicated, ${ }^{12}$ and Rule violations pres-

* Angela M. Vallario is a Visiting Assistant Professor at Howard University School of Law; B.S. University of Florida; J.D., University of Baltimore; LL.M. (Taxation) Georgetown University Law Center.

1. John Chipman Gray, The Rule Against Perpetuities 191 (4th ed. 1942).

2. Md. CODE ANN., Est. \& TRUSTS \& 11-102(e) (Supp. 1998).

3. 765 Ill. COMP. STAT. 305/2-6 (West 1993 \& Supp. 1998).

4. ALASKA STAT. § 34.27.050(a)(3) (Michie 1998).

5. DEL. CODE ANN. tit. 25, \& 503(a) (Supp. 1998).

6. S.D. Codified Laws $\S 43-5-8$ (Michie 1997).

7. Wis. STAT. ANN. $\$ 700.16$ (West 1997 \& Supp. 1998).

8. IDAHO CODE $\S 55-111$ (1994).

9. This article will focus on the irrevocable dynasty trusts designed to benefit multiple beneficiaries for numerous generations. It is created to last forever and avoids the rule against perpetuities.

10. The Delaware preamble states that Delaware's abolishment legislation was enacted to "[k]eep Delaware competitive in the trust capital." Jesse Dukeminier, Dynasty Trusts: Sheltering Descendants From Transfer Taxes, 23 EST. PLAN. 417, 422 (1996) [hereinafter Dukeminier, Dynasty Trusts].

11. See infra Part V.C.1-2.

12. See infra note 13; however, some scholars note that there are other areas within American law far more complex than the Rule. Raymond C. O'Brien, Analytical Principle: A Guide for Lapse, Survivorship, Death Without Issue and the Rule, 10 GEO. MASON L. REV. 383 (1988). 
ent harsh consequences for practitioners and their clients. In fact, violations of the Rule, due to its complexity, have been held as an attorney error, not subject to a malpractice claim. ${ }^{13}$ The complexities of the Rule and the harsh consequences for the violations thereof, initiated and resulted in the variations of reform.

American reform doctrines, such as the "wait and see", Uniform Statutory Rule Against Perpetuities (USRAP) and cy pres have altered the strict requirements of the Rule. The reform doctrines make determinations as to the vesting of contingent interests based on actual events ("wait and see"), ${ }^{14}$ extend the vesting period to ninety years (USRAP) ${ }^{15}$ or permit equitable reformation to fix Rule violations (cy pres). ${ }^{16} \mathrm{~A}$ vast majority of the jurisdictions have adopted one form or another of the reform doctrines. ${ }^{17}$ Even so, the common law Rule remains in twenty-one jurisdictions. ${ }^{18}$

A brief discussion of the origin of the Rule, basic elements and the modern reform, are useful for a fuller understanding of this article's critique of the abolishment legislation. After the brief discussion of the Rule and reform, this article categorizes the abolishment legislation as the 1998 abolishment legislation; ${ }^{19}$ the additional-incentive jurisdictions ${ }^{20}$ and the forerunners of abolishment. ${ }^{21}$ After categorizing the abolishment legislation, this article compares the arguments against the abolishment legislation to its advantages. Furthermore, this article emphasizes that the abolishment legislation has ignored dead hand control in favor of providing wealthy settlors with an estate planning tool to minimize federal transfer taxes. In conclusion, this article suggests that in light of the consequences of dead hand control the abolishment legislation should be stopped. Failure to stop the trend among jurisdictions could result in the Federal government curtailing dead hand control.

\section{Background}

The Rule attempts to limit dead hand control by prohibiting the remote vesting of contingent interests. ${ }^{22}$ Whether or not an interest violates the Rule depends on whether or not vesting of a future interest occurs within the Rule's period. ${ }^{23}$ The effect of the Rule is that to the extent that the vesting occurs beyond the Rule's period

13. Lucas v. Hamm, $56 \mathrm{Cal} .2 \mathrm{~d} .583,364$ P.2d 685, (1961). In that case a beneficiary brought a malpractice action against an attorney who drafted a residual testamentary trust which violated the Rule. The Supreme Court of California noted that an attomey who renders legal services agrees to use such skill, prudence, and diligence as lawyers of ordinary skill. Due to the complexities of the Rule, an attorney of ordinary skill could have misapplied the rule and therefore is not liable for malpractice.

14. See infra Part IV.A.

15. See infra Part IV.B.

16. See infra Part IV.C.

17. Eight jurisdictions have adopted wait and see; twenty-four jurisdictions have adopted USRAP; seven jurisdictions have adopted cy pres.

18. Jurisdictions adhering to common law Rule include: Alabama, Arkansas, the District of Columbia, Iowa, Kentucky, Louisiana, Maine, Mississippi, Missouri, New Hampshire, New York, Ohio, Oklahoma, Pennsylvania, Rhode Island, Texas, Utah, Vermont, Virginia, Washington and Wyoming. Dukeminier, Dynasty Trusts, supra note 10, at 419 . Most of these jurisdictions have also adopted one of the reform doctrines to alleviate the strict requirements of the Rule. Id.

19. The 1998 abolishment legislation includes Maryland and Illinois. See infra Part V.B.1.

20. Additional incentives such as asset protections and no requirement of fiduciary income tax returns are offered in Alaska, Delaware and South Dakota. See infra Part V.B.2.

21. The forerunners at enacting the abolishment legislation include Wisconsin and Idaho. See infra Part V.B.3.

22. JeSSE DUKEMINIER \& JAMES E. KRIER, PROPERTY 291 (4th ed. 1998) [hereinafter DUKEMINIER, PROPERTY].

23. The Rule's period is the measuring life plus 21 years. See infra Part III. 
the interest is void. ${ }^{24}$

The Rule had its origins in the seventeenth century and was the result of a compromise between wealthy landowners who desired to keep land within the family and royal judges who tried to resist such efforts. ${ }^{25}$ The wealthy landowner, in an attempt to accomplish this objective, used many forms of land settlement involving future interests to control his property after his death. ${ }^{26}$ Such "dead hand" control effectively restricted the alienability of land and consequently the sociological and economic impact was significant. ${ }^{27}$

The Duke of Norfolk's Case ${ }^{28}$ was the first successful move by the royal judges to limit the dead hand control. ${ }^{29}$ In the Duke of Norfolk's Case the courts permitted the settlor to control the disposition of property for a person's lifetime (the measuring life), ${ }^{30}$ provided the life existed at the time the interest was created. ${ }^{31}$ This was viewed by courts to be a reasonable limitation on the settlor's control on property. The settlor was permitted to exercise his judgment and control as to any then-living beneficiaries and their abilities to handle the rights and responsibilities of property ownership. ${ }^{32}$ Eventually the reasonable period of dead hand control was extended to account for the unborn infant/beneficiary. ${ }^{33}$ Courts subsequently permitted the settlor to restrict the alienability of land and exercise dead hand control and hinder marketability for a time period as long as that of the measuring life plus twenty-one years. ${ }^{34}$

Although the Rule was set out in the Duke of Norfolk's Case, Professor Gray was the first person to articulate the Rule with its widespread notoriety "no interest is good unless it must vest, if at all, not later then twenty-one years after some life in being at the creation of the interest." 35

In summary, the Rule was the result of a compromise between the interests of wealthy landowners and judges trying to prevent the dead from controlling the fu-

24. Thomas f. Bergin \& Paul G. Haskell, Preface to estates In Land and future InTERESTS 179 (2d ed. 1984).

25. Dukeminier, Property, supra note 22, at 291.

26. BERGIN, supra note 24 , at 179.

27. Id.

28. 3 Ch. Cas. 1, 22 Eng. Rep. 931 (1681).

29. The facts of this famous case, known for implementing the Rule arose when the wealth of the Earl of Anundel was at risk of passing his estate to his eldest insane son. By law, the eldest son was entitled to his father's wealth. Earl did not want his property to go to his insane son; instead he wanted to control the property from his grave. Earl of Arundel enlisted the help of his lawyer to a create trust to protect his family from his eldest son's actions. The Court acknowledged that Earl of Arundel's concern was legitimate, and developed a reasonable period during which Earl's judgment could prevail. According to the court, the father could realistically recognize the capabilities of living members of his family, and so, with respect to them, the father's informed judgment solemnly inscribed in an instrument was given effect. The Earl was permitted to control only so long as his judgment was informed with an understanding of the capabilities and needs of persons alive when the judgment was made.

30. See infra Part III.

31. DUKEMINIER, PROPERTY, supra note 22, at 291.

32. Id.

33. After almost 150 years of applying the Rule, the courts fixed the period during which the setthor could exercise dead hand control to the measuring life plus 21 years to account for a contingent interest vesting in favor of a minor. Cadell v. Palmer, I Cl. \& F. 372 (1833).

34. DUKeminier, Property, supra note 22, at 299.

35. See GrAY, supra note 1; see also BERGIN, supra note 24, at 178; DUKEMINIER, ProperTY, supra note 22, at 291 . 
ture. $^{36}$ The compromise is that property may be tied up in contingent interests for lives in being plus twenty-one years, but no longer. ${ }^{37}$ In effect, a landowner could "provide for all of those in his family whom he could have personally known and the first generation thereafter attaining majority." 38

\section{Basic Elements of the Rule}

The Rule voids a contingent interest ${ }^{39}$ that may not necessarily vest or fail within a measuring life ${ }^{60}$ plus twenty-one years (common law Rule period). ${ }^{41}$ The common law Rule permits a trust to endure for selected lives in being at the creation of the trust $^{42}$ plus twenty-one years. ${ }^{43}$ For example, a testator at death, ${ }^{44}$ may transfer property into a trust for the benefit of his children for life and then to his grandchildren who reach age twenty-one. ${ }^{\text {ts }}$ The trust will last for the lives of his children plus twenty-one years. If the child was ten at the trust's creation ${ }^{46}$ and he or she lives to seventy, the trust can endure for eighty-one years (sixty years for the life in being plus an additional twenty-one years). This article will only address the contingent remain$\operatorname{der}^{47}$ in a dynasty trust. ${ }^{48}$ The Rule does not require that the trust terminate within the Rule period, but does require that the contingent interests vest or fail within that period. The abolishment legislation permits the trust to last forever and does not require the contingent interest to vest or fail to vest. 49

In analyzing an interest under the Rule, one must first determine whether the interest is subject to the Rule's application. ${ }^{50}$ To determine if an interest violates the

36. See supra notes $28-29$.

37. The wealthy decedent can control disposition of property for the lifetime of the person whose propensities he or she may know or fear and for 21 years thereafter. It denies the wealthy decedent the right to control disposition of property beyond 21 years after the death of the persons alive at creation.

38. 6 AM. L. OF PROP. \$ 24.16 (1952).

39. Contingent interests include contingent remainders and executory interests. Vested interests are exempt. The possibility of reverter and right of entry are not included. See O'Brien, supra note 12. This article only addresses the contingent remainders in a dynasty trust.

40. See infra Part III.

41. John K. Phoebus, The Rule Against Perpetuities-The Implication of a Reasonable Time for the Performance of a Contingency to the Vesting of Future Interests in Commercial Transactions-Maryland's Hybrid Approach to the Rule Against Perpetuities in Commercial Contexts, 101 DiCK. L. REV. 619, 621 (1997).

42. See infra Part II.

43. GRAY, supra note 1 .

44. The creation of the interests is at the death of the Testator.

45. The interest left to the grandchildren is a contingent remainder to which the Rule applies. The interest is subject to a condition precedent that must occur prior to taking. The condition precedent is the grandchild reaching age 21 . Thus the Rule applies to this interest.

46. Because the transfer is by will, the creation is at the testator's death.

47. A contingent remainder is subject to a condition precedent or owned by unascertained persons. BERGIN, supra note 24, at 73 . Executory interests are also govemed by the Rule but not addressed in this article. See supra note 39.

48. A dynasty trust sometimes referred to as the perpetual or generation-skipping transfer trust is generally a future interest trust intended to benefit multiple beneficiaries in multiple generations and continue forever. Dukeminier, Dynasty Trusts, supra note 10.

49. For the above example, the abolishment legislation would permit the settlor to transfer property into a trust for the lives of his children, grandchildren, great-grandchildren and future generations. All interests could be conditioned on survivorship. There would be no requirement that a measuring life or measuring lives be in existence at the creation of the interests.

50. Contingent remainders are always subject to the Rule. DUKEMINIER, ProperTy, supra note 22, at 266. 
Rule, an interest is judged prospectively from the time of the interest's creation, without regard to events that occur after the interest's creation. According to W. Barton Leach, a scholar, critic and whose writings ${ }^{51}$ initiated much of the American reform of the Rule:

[A] future interest is invalid unless it is absolutely certain that it must vest within the period of perpetuities. Probability of vesting, however great, is not sufficient. Moreover, the certainty of vesting must have existed at the time when the instrument took effect.... It is immaterial that the contingencies actually do occur within the permissible period or actually have occurred when the validity of the instrument is first litigated..$^{52}$

In order to determine if the interest will vest within the Rule period, a measuring life must be identified. ${ }^{53}$ One specific person, alive at the time of the creation of the interest, need not be singled out and identified as the measuring life, provided the interest vests within the life of one person, among a definable group of persons, plus 21 years. $^{54}$

If the will or trust is drafted with a contingent interest which violates the Rule, the interest may not be void if the will or trust was drafted in a jurisdiction that recognizes one of the various reform doctrines ${ }^{55}$ or included a savings clause. ${ }^{56}$

\section{Modern Reforms to the Rule}

Since the Cadell v. Palmer ${ }^{57}$ case in 1833 , the common law Rule has undergone tremendous reform in England ${ }^{58}$ as well as in America. ${ }^{59}$ Reform was brought about largely as a result of the absurd consequences of strict compliance with the Rule. ${ }^{60}$ In America, there have been many efforts and many doctrines adopted to reduce the effects of the Rule and to remedy the violations thereof. Some of these reform doctrines include the "wait and see" doctrine, the Uniforms Statutory Rule Against Perpetuities (USRAP) and cy pres."

51. See infra note 71.

52. W. Barton Leach, Perpetuities in a Nutshell, 51 HARv. L. REV. 638 (1938) [hereinafter Leach, Nutshell].

53. A contingent interest must vest within the life of, or at the death of the person, or within 21 years after the death of the person. That person is the measuring life. A measuring life can be a preceding life tenant, the taker or takers of the contingent interest, anyone who can affect the identity of the takers, and anyone who can affect a condition precedent. DUKEMINIER, PROPERTY, supra note 22.

54. BERGIN, supra note 24, at 181; see also Fitchie v. Brown, 211 U.S. 321 (1908); Dickson v. Renfro, 569 S.W.2d 66 (Ark. 1978); Wing v. Wachovia Bank \& Trust Co., 241 S.E.2d 397 (N.C. 1978).

55. See infra Part IV.

56. A savings clause is a trust or will provision that provides for the termination or distribution in the event of a Rule violation. See Dukeminier, Dynasty Trusts, supra note 10, at 3-4.

57. Cadell, 1 Cl. \& F. 372

58. The Perpetuities \& Accumulations Act, 1964, ch. 55. For a more detailed discussion of the reform doctrines adopted in England, see W. Barton Leach, Perpetuities Reform by Legislation: England, 70 HARv. L. Rev. 1411 (1957) [hereinafter Leach, Perpetuities Reform]; Robert J. Lynn, Perpetuities Reform: An Analysis of Developments in England and the United States, 113 U. PA. L. REV. 508 (1965).

59. See infra Part IV.A-C.

60. See W. Barton Leach, Perpetuities Legislation: Hail Pennsylvania!, 108 U. PA. L. REV. 1124 (1960) [hereinafter Leach, Hail Pennsylvania]. See infra note 66.

61. For a brief description of the reform doctrines, see infra Part IV.A-C. 
Professor Leach, a leading authority in the field and instrumental in the legislative reform doctrines, once referred to the Rule as a "technically-ridden nightmare". ${ }^{62}$ The Rule's application and harsh consequences ${ }^{63}$ led many scholars and lawyers to call for reform doctrines. ${ }^{64}$ The reform doctrines have alleviated the strict requirements of the historical Rule. ${ }^{65}$ Modern efforts to reform the Rule were widely accepted and welcomed in an effort to reduce the absurd consequences ${ }^{66}$ of the Rule. ${ }^{67}$

\section{A. "Wait and See"}

Jurisdictions that have not eliminated the effect of the Rule have either enacted legislation ${ }^{68}$ or by judicial decision" ${ }^{69}$ adopted the "wait and see" doctrine, which takes a bite out of the Rule. ${ }^{70}$ Professor Leach's position which brought about the "wait and see" reform doctrine is based on the premise that the vesting of contingent interests should reflect actual events as opposed to mere possibilities." Under this doctrine interests are judged, based on actual events as opposed to prospectively examining the interest. ${ }^{72}$ Jurisdictions that follow this approach ${ }^{73}$ will not void an interest for violating the Rule unless an actual event or the actual nonoccurrence of an event prevents an interest from vesting or failing within the Rule's period.

In 1947, Pennsylvania became the first jurisdiction to adopt the broad "wait and see" doctrine now adopted in eight states. ${ }^{74}$ One jurisdiction ${ }^{75}$ has adopted a more limited form of the "wait and see" approach. That jurisdiction waits only until the expiration of the life estates possessed by individuals who were lives in being at the

62. W. Barton Leach, Perpetuities Legislation Massachusetts Style, 67 HARV. L. REV. 1349 (1954) [hereinafter Leach, Massachusetts Style].

63. See Dickerson v. Union, 595 S.W.2d 677 (Ark. 1980). This case is know as the "unborn widow case". In Dickerson, the Testatrix created a trust to continue "until the death of both sons and one son, Martin's widow and until the youngest of either son has reached the age of twenty-five years." The court held the trust violated the rule since the son's "widow" might not be bom at the Testatrix's death.

64. W. Barton Leach, Perpetuities in Perspective: Ending the Rules' Reign of Terror, 65 HARV. L. REv. 721,739-41 (1952) [hereinafter Leach, Perpetuities in Perspective].

65. The reform relief is primarily from not mandating that the interest be judged prospectively based on a mere possibility that the interest could fail.

66. See Jee v. Audley 29 End. Rep 1186 (1787). In Jee, a contingent interest violated the Rule because of the absurd possibility that a 70-year old woman might bear children. This case gained wide notoriety as the fertile octogenarian situation, that a person is always presumed to be able to have children regardless of age or physical condition. DUKEMINIER, PROPERTY, supra note 22, at 311.

67. RESTATEMENT (SECOND) OF PROPERTY.

68. See infra note 74 .

69. New Hampshire adopted wait and see by judicial decision. Merchants National Bank v. Curtis, 97 A.2d 207 (N.H. 1953).

70. DUKEMINIER, PROPERTY, supra note 22, at 312.

71. Leach, Nutshell, supra note 52; Leach, Hail Pennsylvania, supra note 60; Leach, Massachusetts Style, supra note 62; Leach, Perpetuities in Perspective, supra note 64; W. Barton Leach, The Rule Against Perpetuities and Gifts to Classes, 51 HARV. L. REV. 1329 (1938); W. Barton Leach, Powers of Sale in Trustees and The Rule Against Perpetuities, 47 HARV. L. REv. 948 (1934).

72. Phoebus, supra note 41 .

73. Infra notes 74-75.

74. PA. STAT. ANN. tit. 20, $\S 301.4-5$ (1950). The other seven states are: Iowa, Kentucky, Ohio, Rhode Island, Vermont, Virginia, and Washington. See IOWA CODE ANN. $\$ 558.68$ (West 1992); KY. ReV. STAT. ANN. \$ 381.216 (Michie 1972 \& Supp. 1996); OHIO Rev. CoDE ANN. \$ 2131.08c (West 1998); R.I. GEN. LAwS § 34-11-38 (1995); VT. STAT. ANN. tit. 27, § 501 (1998); VA. Code ANN. § 55-13.3 (Michie 1995); WASH. REV. CODE $\S \S 11.98 .130,11.98 .900$ (1998).

75. Maine is the only jurisdiction using this approach. ME. REv. STAT. ANN. tit. 33, $§ 101$ (West 1998). Prior to the abolishment legislation Maryland also was a limited wait and see jurisdiction. 
time the interest was created to determine if the contingent interest will vest or fail within twenty-one years of that time. ${ }^{76}$

\section{B. Uniform Statutory Rule Against Perpetuities}

In addition to the above-mentioned variations of the "wait and see" doctrine, a majority of the jurisdictions have adopted the USRAP." USRAP validates interests that comply with the common law Rule. In the event that the interest does not comply with the common law Rule all interests will be valid if they actually vest within a 90year "wait and see" period. If the interests do not actually vest within 90 years, a court will reform the trust to comply with the settlor's intent. ${ }^{78}$

Therefore, the common law justification of permitting settlors to control only property during the lives of persons who they know and whose ability they can judge plus 21 years thereafter was virtually eliminated by jurisdictions adopting the USRAP. ${ }^{79}$ USRAP allows the drafter to specify which period (common law Rule period or 90-year "wait and see" period) governs trust termination. The settlor can not select the longer Rule period based on actual events. ${ }^{80}$

\section{Cy Pres}

Reform is also permitted under the cy pres doctrine. ${ }^{81}$ The cy pres doctrine al-

76. Id.

77. Currently 24 jurisdictions have adopted USRAP including: Alaska, Arizona, California, Colorado, Connecticut, Florida, Georgia, Hawaii, Indiana, Kansas, Massachusetts, Michigan, Minnesota, Montana, Nebraska, Nevada, New Jersey, New Mexico, North Carolina, North Dakota, Oregon, South Carolina, Tennessee and West Virginia. See Alaska STAT. $\$ \$ 34.27 .050-34.27 .090$ (Michie 1.998) ; ARIZ. Rev. STAT. ANN. \$\$ 14-2901-14-2906 (West Supp. 1997); CaL. Prob. CoDE $\$ \S 21200-21231$ (West Supp. 1994); Colo Rev. STAT. ANN. \$§ 15-11-1101 to 15-11-1107 (West 1997); ConN. Gen. STAT. ANN. $\$ \S 45 \mathrm{a}-490$ to $45 \mathrm{a}-496$ (West 1993); FlA. STAT. ANN. $\$ \S 689.225$ (West 1994); GA. CODE ANN. $\S \S 44-6-200$ to 44-6-206 (1998); HAW. REV. STAT. ANN. $\$ \S 525-1$ to 525-6 (Michie 1993); IND. CODE ANN. \$§ 32-1-4.5-1 to 32-1-4.5-6 (Michie 1995); KaN. STAT. ANN. $\S \S 59-3401$ to 59-3408 (1994); MASS. GEN. LAWS ANN. ch. 184A \& 1-11 (West 1991); MICH. COMP. LAWS ANN. §§ 554.71554.78 (West Supp. 1998); MINN. STAT. ANN. \$§ 501A.01-501A.07 (West 1990); MONT. CODE ANN. $\S \S 72-2-1001$ to $72-2-1007$ (1997); NEB. REV. STAT. $\$ \$ 76-2001$ to 76-2008 (Michie 1995); NEV. REv. Stat. ANN. $\S \S 111.103-111.1039$ (Michie 1998); N.J. STAT. ANN. $\$ \S$ 46:2F-1-46:2F-8 (West Supp. 1997) ; N.M. STAT. ANN. $\$ \$ 45-2-901$ to $45-2-906$ (Michie 1998); N.C. GEN. STAT. $\$ \S 41-15$ to 41-22 (1998); N.D. CENT. CODE $\$ \$ 47-02-27.1$ to 47-02-27.5 (1997); OR. REv. STAT. $\$ \S 105.950-$ 105.975 (1995); S.C. CODE ANN. $\$ \S 27-6-10$ to 27-6-80 (Law Co-op. 1991); TENN. CODE ANN. $\$ \$$ 66-1-201 to 66-1-208 (1999); W. VA. CODE §§ 36-1A-1 to 361A-8 (1997).

78. Perpetuities Table of Jurisdictions, Uniform Law Annotated, Master Edition 8B U.L.A. 41 (Supp. 1996).

79. USRAP abandons the idea of the Rule period being tied to a measuring life in existence at the time of the creation. Defining the Rule period in this way was based on the policy that it was reasonable to allow donors to control property during the lives of persons they could have known and whose abilities they could judge. DUKEMINIER, PROPERTY, supra note 22 , at 314 . However, some scholars believe that the 90 -year wait and see period is justified because it was less confusing than identifying a measuring life. See Mary L. Fellows, Testing Perpetuity Reform: A Study of Perpetuity Cases 1984-89, 25 REAL PROP PROB. \& TR. J. 597 (1991). The adoption of the USRAP reform by jurisdictions has abandoned the initial basis of the Rule period being tied to a measuring life plus 21 years. The policy arguments against USRAP reform is beyond the scope of this article.

80. However, a special power of appointment can be given to a donee to subsequently change the perpetuity period.

81. Idaho, lowa, Kentucky, Missouri, Ohio, Rhode Island Vermont have adopted a Cy pres statute. See IDAHo CODE § 55-111 (1994); IOWA CODE ANN. § 558.68 (West 1992); KY. REV. STAT. ANN. § 381.216 (Michie 1972 \& Supp. 1996); Mo. ANN. STAT. $\S 442.555$ (West 1986); OHIO REv. CODE ANN. § 2131.08 (Anderson 1998); R.I. GEN. LAWS \& 18-4-1 (1996); VT. STAT. ANN. tit. 14 \& 2328 (1998); BERGIN, supra note 24, at 178-80; Phoebus, supra note 41 . 
lows courts to reform interests so that they will not violate the Rule. ${ }^{82} \mathrm{~A}$ broad version of this doctrine permits equitable reformation to modify any transaction that would violate the Rule. ${ }^{83}$ A more limited version of cy pres applies only to invalid age contingencies, allowing courts to reduce the age contingency to 21 years, thus saving the interests. ${ }^{84}$

The existence of the reform doctrines minimizes the harsh results of violations of the Rule. The common law Rule reform was intended to "disturb the common law rule as little as possible." ${ }^{85}$ Despite the overwhelming existence of reform, jurisdictions are abolishing the Rule to minimize transfer taxes for wealth settlors and generate income for the banking industry.

\section{Abolishment of the Rule}

\section{A. Overview of Abolishment Legislation}

Most recently, legislators have been taking an aggressive stand towards abolishing the Rule for interests in trusts with private beneficiaries (hereinafter abolishment legislation). The abolishment legislation permits a settlor to create a dynasty trust. ${ }^{86}$ The legislation has been enacted to provide a wealthy settlor with another vehicle by which he or she can minimize transfer taxes and to provide the state with a "carrot" to attract trust business to its state and allow the banking industry to profit. ${ }^{87} \mathrm{~A}$ settlor is free to create an inter vivos trust in any jurisdiction that he or she chooses. ${ }^{88}$ Therefore, the abolishment legislation creates an incentive for a non-resident settlor to create an inter vivos trust in a jurisdiction that has enacted said legislation. Creating an inter vivos trust in an abolishment legislation jurisdiction will allow trust assets to be administered in that jurisdiction and trust companies will generate income therefrom. Furthermore, the legislation may generate additional revenue by way of income tax. ${ }^{89}$

There are three categories of abolishment legislation. The 1998-abolishment legislation, which includes Maryland ${ }^{90}$ and Illinois. ${ }^{91}$ These jurisdictions have similar requirements and became effective in 1998. The additional-incentive jurisdictions are

82. ME. Rev. Stat. ANN. tit. 33, § 101 (West 1998).

83. California adopted full-scale cy pres in 1963. CAL CIv. CodE $\$ 715.5$ (West Supp. 1964).

84. Id.

85. Commissioner report on subsection $9(\mathrm{~b})$ reprinted in 20 PA. CONST. STAT. ANN. $\$ 6104$ (1998); Phoebus, supra note 41 . But see supra note 79.

86. See supra note 48 for definition of dynasty trust.

87. See fiscal analysis of Maryland Bill which states "due to the rule against perpetuities, all trusts in Maryland generally must terminate between 80 to 110 years after creation. Several others states have modified the rule against perpetuities in order to permit the creation of the perpetual dynasty trust. Therefore, a Maryland resident can currently create a perpetual dynasty trust, but only if the trust is located in a state that modified the rule against perpetuities in this regard (i.e., if the trust is administered by a banking institution located in one of those states). As a result of the [abolishment legislation] bill, Maryland banks could administer perpetual dynasty trusts." H.B. 495 (Md. 1998).

88. Trust law is a creature of state law. Wilmington Trust Co. v. Wilmington Trust Co. 24 A.2d 309, 313 (Del. 1942). The jurisdiction of domicile controls testamentary trusts whereas a settlor may forum shop for a desirable jurisdiction for his or her inter vivos trust.

89. Maryland's fiscal analysis indicates that state income tax revenues could increase to the extent that Maryland banks receive additional income in the form of trust administration fees. See Md. $\mathbf{H}$. Res. 495; see infra Part V.B.2.

90. Testamentary or inter vivos trusts created on or after October 1, 1998 are governed by the Maryland abolishment legislation. See supra note 2.

91. Testamentary or inter vivos trusts created on or after January 1, 1998 are governed by the IIlinois abolishment legislation. See supra note 3. 
Alaska, ${ }^{92}$ Delaware, ${ }^{93}$ and South Dakota. ${ }^{94}$ These jurisdictions do not impose an income tax on the income generated by the fiduciary of the dynasty trust and protect trust assets from the settlor's creditors. The third category groups the forerunners of the abolishment legislation, Wisconsin ${ }^{95}$ and Idaho. ${ }^{96}$ The forerunner jurisdictions pre-dated the other abolishment legislation by more than a decade and were enacted for different reasons. The following discussion does not discuss the individual legislation, but discusses the legislation as categorized.

\section{B. The Abolishment Legislation}

\section{The 1998-abolishment legislation}

Maryland ${ }^{97}$ and Illinois ${ }^{98}$ were the most recent jurisdictions to enact abolishment legislation. These jurisdictions allow estate planners to draft trust documents with contingent interests that avoid the Rule. ${ }^{99}$ The 1998 -abolishment legislation requires that the trust document express the settlor's intent to avoid the Rule ${ }^{100}$ and the trustee is given the power to "sell, lease or mortgage property for any period beyond the period of the rule against perpetuities". ${ }^{101}$

The 1998-abolishment legislation was enacted to encourage and/or keep trust business within the state's boundaries and appears to be a direct response to other legislation previously enacted. ${ }^{102}$ Maryland and Illinois wanted to discourage its residents from taking trust business to neighboring jurisdictions ${ }^{103}$ where dynasty trusts were permitted. ${ }^{104}$ The advantages gained from allowing a settlor to create a dynasty trust are that wealthy settlors can minimize transfer taxes, ${ }^{105}$ trustees will generate

92. Alaska Stat. § 34.27.050(a)(3) (Michie 1998).

93. DEL. CODE ANN. tit. 25, § 503(a) (Supp. 1998).

94. S.D. CODIFIED LAwS \& 51A-6A (Michie 1997).

95. Wisc. Stat. ANN. \& 700.16 (West $1997 \&$ Supp. 1998).

96. IDAHO CODE \$ 55-111 (1994).

97. See supra note 2 for trusts executed or amended on or after October 1, 1998.

98. See supra note 3. Effective August 17, 1997 for trusts created on or after January 1, 1998.

99. The Rule is avoided by expressing an intent to avoid the Rule and including amongst the trust terms the trustee's ability to buy and sell trust assets.

100. Under Maryland law, the goveming instrument must state that the Rule Against Perpetuities does not apply to the trust. MD. CODE ANN., EST. \& TruSTS § 11-102(e) (Supp. 1998). The Illinois statute uses the term "qualified perpetual trust" which requires specific trust terms to dictate that the rule against perpetuities does not apply. 765 ILL. COMP. STAT. $§ 305 / 3(a-5)(i)$ (West 1993 \& Supp. 1998).

101. Id. § 11-102(e); 765 ILL. CoMP. STAT. § 305/3(a-5)(i)-(ii).

102. Five jurisdictions had enacted the abolishment legislation at the time the 1998-abolishment legislation was being considered. Those jurisdictions include Illinois, Alaska, Delaware, South Dakota, Wisconsin and Idaho. Furthermore, Maryland's fiscal analysis states that a Maryland resident could create a dynasty trust in other jurisdictions. See Md. H. Res. 495.

103. Delaware and Wisconsin had previously enacted abolishment legislation at the time the Maryland and Illinois enacted the 1998-abolishment legislation. It is obvious that the 1998-abolishment legislation was enacted due to the potential threat of loosing trust business to these neighboring states.

104. DEl. Code ANN. tit. 25, § 503 (Supp. 1998); WIS. STAT. ANN. $§ 700.16$ (West 1997 \& Supp. 1998)

105. Wealthy settlors minimize transfer taxes by placing assets in trust and providing the further generations of beneficiaries with only a life estate which is not subject to an additional transfer tax at the beneficiaries' subsequent death. I.R.C. $\S 2036$ (1998). However, to the extent the trust assets are available for a generation more than one generation removed from the settlor (skip generations) the transfer in trust may be subject to a generation skipping transfer tax. See infra Part V.C.3. 
additional revenue, and additional income tax will be generated for the state. ${ }^{106}$ Lawmakers justified the legislation, without any reference to or limitation on dead hand control. The 1998-abolishment legislation implied that the generation-skipping transfer tax imposes sufficient controls on the wealthy dead hand..$^{107}$

It is not surprising that the bankers' association heavily supported the abolishment legislation. ${ }^{108}$ The 1998 -abolishment legislation virtually had no opposition. ${ }^{109}$ There was no support for retaining the Rule and its reform doctrines for contingent interests in trusts with private beneficiaries. Consequently, dead hand control returns for such interests. Thus, the Rule, which originated as a reasonable limitation on dead hand control, no longer reflects this historical compromise. ${ }^{10}$ It is apparent that wealth has prevailed. The wealthy settlor who desires to exercise dead hand control may do so by testamentary or inter vivos trust."'

In sum, the 1998-abolishment legislation has identical requirements: (1) that the settlor's intent to avoid the Rule be clear from the trust terms and (2) that the trustee have the ability to sell trust assets. ${ }^{12}$ The drafter can create dynasty trusts, allowing the trusts to remain in existence forever, thus dead hand control returns. The legislation was motivated by jurisdictions competing for trust business. Additionally, wealthy settlors minimize transfer taxes, ${ }^{113}$ and additional income is generated, ${ }^{114}$ as a result of settlors creating trusts in these jurisdictions and corporate trustees, ${ }^{115}$ primarily the trust banking companies, ${ }^{116}$ earning additional trust commissions and paying additional income taxes.

106. See supra note 89.

107. Maryland's fiscal analysis further demonstrated a wealthy settlor's ability to minimize estate taxes by noting that the dynasty trust would be especially suited for transfers within the settlor's onemillion dollar generation skipping transfer tax exemption. The analysis stated that transfers within the settlor's one-million dollar exemption received favorable transfer tax advantages, implying that settors would not likely make transfers in excess of the generation-skipping transfer tax exemption, thus the one-million dollar exemption was a sufficient limitation on dead hand control. See Md. H. Res. 495; see infra Part V.C.3.

108. In Maryland the Maryland Bankers' Association testified on behalf of the legislation and was listed as the Information Source. See Md. H. Res. 495.

109. No one from the academic community was contacted regarding the Maryland 1998-abolishment legislation. There was no testimony in favor of retaining the Rule and its current reform, which then permitted property to be held in trust for 80 to 110 years after its creation. See supra note 87.

110. See supra Part II.

111. If the individual is domiciled in an abolishment legislation jurisdiction using a testamentary or inter vivos trust or if the settlor is not domiciled in an abolishment legislation jurisdiction by forum shopping and creating an inter vivos trust.

112. MD. CODE ANN., EST. \& TRUSTS \& 11-102(e) (Supp. 1998); 765 ILL. CoMP. STAT. § 305/3(a5)(i)-(ii) (West 1993 \& Supp. 1998).

113. See infra Part V.D.1.

114. The 1998-abolishment legislation is expected to result in "a minimal increase in general funds revenue" as a result of the increased corporate income tax generated by trust companies from the additional trustee commissions earned from administering the dynasty trusts. See Md. H. Res. 495.

115. A settlor may select a corporate or individual trustee. A corporate trustee is the better candidate for the position because of the continuity in management that can be provided. A dynasty trust will last several generations and an entity is the only trustee, which endure forever like the perpetual trust.

116. With the creation of a perpetual trust designed to last forever, it is likely that corporate trustees will be selected. The indefinite duration of corporate trustees encourages its selection over an individual trustee with successor trustees named. The problem with naming individual trustees and successor trustees is that the settlor can not name unborn individuals. 


\section{Additional incentives are available in Alaska, Delaware and South Dakota}

Like the 1998-abolishment legislation, the abolishment legislation in these additional-incentive jurisdictions permits dead hand control. These states do not impose a fiduciary income tax on the trust income ${ }^{177}$ and/or offer the settlor asset protection. ${ }^{118}$ Asset protection allows trust assets to be insulated from the settlor's creditors and unforeseen circumstances of future generations.

\section{a. Alaska}

In 1997 Alaska amended its statute ${ }^{119}$ to validate an interest in a trust if all or part of the income or principal of the trust may be distributed under the discretion of the trustee to a life in being at the creation of the interest. ${ }^{120}$ If the named trustee is given the power to make discretionary distributions of principal or income to a beneficiary living at the creation, the property interest created in the trust will be valid even if that interest remains contingent for generations.

Unique to the Alaska abolishment legislation is the requirement that a discretionary trust be established in which the trustee has the ability to distribute to a life in being at the trust's creation. ${ }^{121}$ There is no other requirement imposed on the settlor. The trustee is not required to exercise said discretion favorably to beneficiaries. Absent abuse of discretion, the trustee can not be forced to exercise discretion in favor of distributing to a life in being. ${ }^{122}$

\section{b. Delaware}

In 1995 Delaware amended its statute to include personal property. ${ }^{123}$ In Delaware, wealthy landowners were always at liberty to exercise dead hand control. Delaware amended its abolishment legislation for personal property held in a trust as to documents created on or after July $7,1995 .{ }^{124}$ It was clear that Delaware amended its abolishment legislation, in an effort to keep its trust business competitive. ${ }^{125}$

The 1995 amendment to include personal property along with land was brought about at a time in which the traditional notion of land equaling wealth was not necessarily the case. ${ }^{126}$ After the drastic decline in the real estate market across the nation

117. In South Dakota there is no state income tax. S.D. CoDIFED LAws $\$$ 43-5-8 (Michie 1997). This is advantageous for the non-resident settlor or non-resident beneficiary if income tax can be avoided in his domicliary state. See Pierce H. McDowell, The Dynasty Trust: Protective Armor for Generations to Come: Special Use Trusts, 132 TR. \& EST. 47-54 (1993). Delaware for example, does not have a state fiduciary or capital gains tax on trust accumulations for non-resident beneficiaries.

118. ALASKA STAT. $\S \S 13.12 .205(2)(A), 13.36 .035(a),(c), 13.36 .045(a)(2), 13.36 .310,13.36 .390$, 34.27.050(a)(3), 34.40.010 (Michie 1998) (amending the Alaskan trust law to protect settlor's assets from creditors. See also Joel C. Dobris, Changes in the Role and the Form of the Trust at the New Millennium, or, We Don't Have to Think of England Anymore, 62 ALB. L. REV. 543, 578 n.60 (1998).

119. Alaska previously recognized USRAP reform.

120. Alaska STAT. $\$ 34.27 .050($ a)(3) (Michie 1998).

121. Id.

122. Restatement (SECOND) OF TRUSTS \& 187 (1959).

123. Del. CODE ANN. tit. 25, \& 503(a) (Supp. 1998).

124. Id.

125. Id.; Dukeminier, Dynasty Trusts, supra note 10, at 422-23.

126. Wealth today has changed from real property to personal property that is readily liquid such as stocks, bonds, mutual funds and interest-bearing bank accounts. See O'Brien, supra note 12, at 383 n.2. 
suffered in the early 1990's, Delaware was quick to act in amending its legislation to provide the once wealthy landowner with the ability to exercise dead hand control over personal property. ${ }^{127}$ The Delaware abolishment legislation was direct in addressing its reason for abolishing the Rule for personal property. The amendment to the Delaware Code states the abolishment legislation was enacted to " $[\mathrm{k}]$ eep Delaware competitive in the formations of trust capital."128 The purpose of the abolishment legislation amendment was expressly to attract trust business to its state.

Delaware's abolishment legislation amendment was clearly made from an economic perspective. The return to dead hand control did not disturb the legislators of Delaware as is obvious from its decision to never adopt the Rule for real property. Delaware was quick to amend its legislation to provide for the change in investments brought about after the decline in the real estate market.

In addition to the dynasty trust, Delaware offers its citizens and non-residents added features not shared with all abolishment legislation jurisdictions. Delaware has no state fiduciary income tax filing requirement and asset protection. ${ }^{129}$ In addition to dead hand control, income tax savings feature and asset protections are added incentives to creating a Delaware dynasty trust.

\section{c. South Dakota}

South Dakota is an added-incentive jurisdiction and offers the features previously mentioned for Alaska and Delaware. However, South Dakota was more than a decade ahead of the other additional-incentive jurisdictions. As early as $1983,{ }^{130}$ the purpose of South Dakota legislation was to attract trust business to the state. ${ }^{131}$ Furthermore, the South Dakota statute permits the formation of a private trust company in its jurisdiction. ${ }^{132}$ There is a $\$ 200,000$ capital requirement and a $\$ 5,000$ application fee, in order to sign on board. ${ }^{133}$

\section{The forerunners of abolishment legislation were Wisconsin and Idaho \\ a. Wisconsin}

In 1976, Wisconsin enacted abolishment legislation. ${ }^{134}$ Wisconsin enacted a statute that put it quite clearly. "[T] force in this state." 135 The Wisconsin statute provides that "[t]here is no suspension of the power of alienation by a trust or by equitable interests under a trust if the trustee has power to sell, either expressed or implied, or if there is an unlimited power to

127. In 1995, land had not been appreciating like it once was and even depreciating in some cases, the stock market was healthy, interest rates were declining and investments in personal property for investors were more attractive than the traditional land investment.

128. Tit. 25, § 503(a); Dukeminier, Dynasty Trusts, supra note 10, at 422-23.

129. Tit. 25, § 503(a); John E. Sullivan, Gutting Rule Against Self-Settled Trusts: How The New Delaware Trust Law Computes With Offshore Trusts, 23 DEL. J. CORP. L. 423 (1998). Asset protection insulates the trust assets from the settlor's creditors.

130. S.D. CoDIFIED LAWS $\S 51$ A-6A (Michie 1998).

131. S.D. CODIFIED LAWS § 43-5-8 (Michie 1997).

132. S.D. CODIFED LAWS $\S 51$ A-6A (Michie 1998).

133. Id. \$§ 51A-6A-19, 51A-6A-6; Thomas H. Foye, Using South Dakota Law for Perpetual Trusts, PROB. \& PROP. (1998).

134. WIS. STAT. ANN. \& 700.16(5) (West 1997 \& Supp. 1998).

135. Id. 
terminate in one or more persons in being." 136

The Wisconsin statute does impose statutory requirements that the trustee have the power to sell or an unlimited power to terminate in order for the trust instrument to avoid the harsh consequences of the Rule.

\section{b. Idaho}

The abolishment legislation started in Idaho, a state primarily of land wealth, in response to a 1949 case from the Idaho Supreme Court, which abolished the Rule. ${ }^{137}$ Idaho adopted what is intended to be a complete system governing alienation of real property ${ }^{138}$ and the common law rule against perpetuities was not in force in that jurisdiction. ${ }^{139}$ Idaho has no suspension rule for personal property. ${ }^{140}$ Idaho's abolishment legislation states that there shall be no rule against perpetuities applicable to real or personal property. Idaho did not limit its abolition legislation to real property but instead enacted broad legislation, which included both real and personal property. Additionally, the Idaho statute, similar to several of the subsequently enacted abolishment statutes, required that the trustee have discretion or the power to sell the trust property to avoid any suspension problems. ${ }^{141}$

The Idaho abolishment legislation, like many of the jurisdictions that eventually followed, failed to statutorily provide the beneficiaries with a means by which premature trust termination could be handled. ${ }^{142}$ Furthermore, permitting the dead hand to control property in the future based on facts unknown to the settlor at the time of creation of the trust could have devastating effects for the beneficiaries and his or her heirs. Idaho's reasoning behind taking the initial step towards abolishment legislation was not to attract trust business to the state of Idaho in 1949 and thereafter. Instead the legislative intent was to deal with the overriding concerns that legislators had in preserving the settlor's intent. ${ }^{143}$ At that time, the policy concerns favoring the reflection of the settlor's intent outweighed the policy justifications behind the common law Rule. $^{144}$

136. Id. $\S 700.16(3)$.

137. Locklear v. Tucker, 203 P.2d 380 (Idaho .1949).

138. IDAHO CODE $\S 55-111$ (1994).

139. Locklear, 203 P.2d at 380.

140. IDAHO CODE $\$ 55-111$ (1994).

141. Id.

142. For example, suppose the settlor, a farmland owner in Idaho, transfers farmland into a trust in which the trustee was given the ability to sell assets. There was no mandatory requirement imposed on the trustee with respect to the distribution of income or principal. At the creation, it was the settlor's intent to keep the farmland within the family forever. At some future time, well after the settlor's death, the expenses of administering the trust far exceeded the income. Small tracts of the property will be sold at discounted values to pay trust expenses. The trustee has no power to terminate. Therefore small tracts of the farm will be sold off indefinitely until all trust assets are gone. Furthermore, trust beneficiaries do not have liquidity to purchase the tracts because the dead as opposed to the living is controlling wealth and deceased settlors did not adequately provide for unforeseen circumstances. The problems that arise with permitting this dead hand control is that even though the trustee has the power to sell, he may not exercise his or her discretion to do so. Small tracts of farmland could eventually be disposed of in a fashion that clearly was not in the best interest of the beneficiaries.

143. Various aspects of trust law, such as the enforcement of a spendthrift trust that thrives on giving great weight to honoring the settlor's intent. Broadway National Bank v. Adams, 133 Mass. 170 (1882).

144. Id. 


\section{The Argument Against Abolishment Legislation}

Although a persuasive argument could be made for the abolishment legislation, ${ }^{145}$ the abolishment legislation ignores the policy argument that property rights belong to the living not the dead. The abolishment legislation allows wealthy settlors to create a dynasty trust and control property for many generations after their death. The Rule's compromise was inspired to prevent inalienability of property and dead hand control. ${ }^{146}$ The trustee's ability to sell trust assets resolves the concern of inalienability. ${ }^{147}$ However, dead hand control is a valid concern and should not be overlooked.

Dead hand control caused by the abolishment: (1) hinders the marketability of property; ${ }^{148}$ (2) perpetuates the concentration of wealth; ${ }^{149}(3)$ is discouraged only by the generation-skipping transfer tax; $;^{150}$ and (4) fails to provide the beneficiaries with a means for terminating the dynasty trust based on unforeseen circumstances. ${ }^{151}$ Problems such as trust assets being unavailable for social needs, debtor-creditor issues, beneficiary resentment, and uninformed forum shopping are also consequences of the settlor exercising unrestricted dead hand control.

\section{Marketability}

Excessive restraints on property ownership destroy the property's marketability. ${ }^{152}$ Dead hand control frustrates the ability of current equitable owners and prospective purchasers to engage in a transaction that could make them both better off. Dynasty trusts may result in inefficient use of resources because of unforeseen contingencies that disadvantage the beneficiaries and community as a whole. ${ }^{153}$ Furthermore, when property is held in a dynasty trust, the persons in possession of the property lose the ability to make decisions based on individual preferences regarding property ownership. ${ }^{154}$

On its face, the abolishment legislation appears to alleviate the lack of marketability caused by dead hand control by requiring that the trustee have the ability to sell trust assets or have the discretion to terminate. ${ }^{155}$ However, the ability to sell trust

145. Dukeminier, supra note 10. According to Dukeminier, in his article addressed to estate planners, the Rule is no longer essential to fulfil the functions of ensuring that property is freely alienable and curtailing dead hand control. Dukeminier further states the usefulness or lack thereof, of the Rule when compared to the complexities and uncertainties and time invested in learning and remembering the Rule and or reform doctrines perhaps makes the abolishment legislation makes a sensible solution.

146. See supra Part II-III.

147. ALASKA STAT. § 34.27.050(a)(3) (Michie 1998); IDAHO CODE § 55-111 (1994); 765 ILL. COMP. STAT. 305/2-6 (West 1993 \& Supp. 1998); MD. CODE ANN., EST. \& TRUSTS $\S 11-102(\mathrm{e})$ (Supp. 1998); WIS. STAT. ANN. \& 700.16 (West $1997 \&$ Supp. 1998).

148. See infra Part V.C.1.

149. See infra Part V.C.2.

150. See infra Part V.C.3.

151. See infra Part V.C.4.

152. DUKEMINIER, PROPERTY, supra note 22, at 283.

153. See, McDowell, supra note 117, at 47 (mentioning editors now requiring sale of Boston Globe was prompted by expiration of family trusts).

154. It is also expected that the dynasty trust will be funded with "keep sake" assets like farmland or ranch interests in a closely held business. Beneficiaries' preferences to retain these assets may be outweighed by trustees making decisions solely from an economic perspective. See SC 28 ALI-ABA $379 \mathrm{H}(1)(\mathrm{b})(\mathrm{d})$.

155. The 1998-abolishment legislation requires that the settlor's intent be expressed and that the 
assets or the discretion to terminate does not mandate the trustee do so, even if the failure to do so is not beneficial for the trust beneficiaries. Dynasty trusts will likely provide the trustee with broad discretion to accommodate various changes in the tax laws. This discretion permits the trustee to make decisions based on changed or unforeseen circumstances not present or known to the settlor at the creation of the trust. ${ }^{156}$ The broad discretion is like a double-edged sword, in that the trustee has the ability to liquidate trust assets or terminate the trust, but no guarantee that the trustee will exercise said discretion. Providing the trustee with broad discretion, absent an abuse of discretion, ${ }^{157}$ beneficiaries will be unable to force the trustee to sell or retain trust assets even if it is in everyone's best interest.

The abolishment legislation favors wealthy settlors' intent to exercise unlimited dead hand control. As a result, assets are tied up in trust arrangements potentially forever and the marketability of the trust assets is hindered which damages not only the beneficiaries but also the community at large. Additionally, the abolishment legislation's mandatory requirement that the trustee have the ability to sell assets does nothing to guarantee marketability. Dynasty trusts will be drafted with broad discretionary powers, to account for changed or unforeseen changes in the law, and such discretion will protect the trustee from being liable for his action regarding the sale or onsale of trust assests. Despite the fact that the abolishment legislation attempts to alleviate the marketability concerns of dead hand control, the abolishment legislation provides no grounds for enforcement by trust beneficiaries.

Wealthy members of one generation control disposition. Even if the trustee has the ability to sell assets, proceeds remain controlled by the trust provisions forever. The wealthy members of one generation should not be permitted to ignore preferences of future generations regarding the use and disposition of property.

\section{Perpetuates the concentration of wealth}

Additionally, the abolishment legislation perpetuates the concentration of wealth. ${ }^{158}$ Abolishment legislation protects the rich from liquidating their property holdings and distributing cash through spending. ${ }^{159}$ If rich beneficiaries cannot make

trustee have the ability to sell trust assets. MD. CODE ANN., EST. \& TRUSTS \$ 11-102(e) (Supp. 1998); 765 ILL. CoMp. STAT. 305/3(a-5)(i)-(ii) (West 1993 \& Supp. 1998). In Alaska the only requirement is that a discretionary trust be established giving the trustee the ability to terminate in favor of a measuring life. ALASKA STAT. § 34.27.050(a)(3) (Michie 1998). Delaware imposes no required trust provision and abolishes the Rule for personality in response to the change in the definition of wealth. DEL. CODE ANN. tit. 25, § 503(a) (Supp. 1998). South Dakota and Wisconsin provide the settlor with the option of giving the trustee the ability to sell or discretion to terminate. S.D. CodifiED LAwS § 43-5-8 (Michie 1997); WIS. STAT. ANN. § 700.16 (West 1997 \& Supp. 1998). Idaho, like the 1998 abolishment legislation, requires that the trustee have the ability to sell trust assets. IDAHO CODE $\S 55-$ 111 (1994).

156. Furthermore because of the nature of the trust, over time the individual trustee, either acting on behalf of a corporate trustee or in his or her individual capacity, is likely to change and be far removed from knowing who the settlor was and what the settlor would have wanted. In light of this anticipated distance between the trustee and settlor, the trustee should be expected to make discretionary decisions from an economic perspective without taking into consideration the settlor's subjective intent.

157. RESTATEMENT (SECOND) OF TRUSTS $§ 187$ (1959). An example of abuse of discretion includes the trustee refusing to terminate to preserve his, her or its trust commission.

158. Phoebus, supra note 41 .

159. See G. Graham Waite, Let's Abolish The Rule Against Perpetuities, 21 REAL EST. L.J. 93 (1993), in which a survey of 48 attorneys reflected that a person should be allowed to make money 
decisions to sell the property then the beneficiaries cannot liquidate their interest and spread wealth around by consuming. The perpetuation of the power and control held by the settlor keeps wealth from being acquired and/or distributed to others.

For example, Bill Gates could create a dynasty trust and concentrate his wealth of $\$ 97,541,600,000$ (hereinafter the Gates' wealth). ${ }^{160}$ If the Gates' wealth is retained in a dynasty trust, assets reinvested at an annual $8 \%$ rate of return and not spread around by beneficiary consumption, after 100 years his accumulation would mount to $\$ 214,568,232,600 .^{161}$ This represents the potential impact that one wealthy individual could have by perpetuating his wealth. The additional accumulation and concentration of wealth by others promotes the rich getting richer and the poor getting poorer. Furthermore, the concentration of wealth may make it impossible for those born outside the umbrella of inherited wealth to break into that chain of wealth. ${ }^{162}$

The concentration of wealth is not healthy for Americans and could lead to unequal treatment based on wealth. ${ }^{163}$ It is essential to a healthy economic society that the wealth accumulation of one generation be placed back into society by the next generation in the way of spending as opposed to continued wealth accumulation. ${ }^{164}$ The abolishment legislation provides an attractive avenue for wealthy individuals to continue accumulation of wealth without the needed spending. The continued accumulation of wealth discourages socialism between the wealthy and others which could ultimately lead to Americans being further separated, further discrimination based on wealth and other sociological and economic consequences.

\section{The generation-skipping transfer tax imposes a nominal limitation on dead} hand control

If dead hand control is promoted and encouraged by abolishment legislation, the only limitation will be the generation-skipping transfer tax (hereinafter sometimes referred to as the GSTT penalty). However, for the extremely wealthy, this may be an insufficient limitation in light of the overall transfer tax advantages to be gained by the abolishment legislation.

The federal estate and gift tax is a transfer tax imposed on the privilege of being able to gratuitously transfer property during lifetime or upon death. ${ }^{165}$ The federal transfer tax system taxes property passing from one generation to the next. The federal transfer tax is imposed to the extent the property transferred exceeds the exemption amounts. ${ }^{166}$ The 1999 exemption for the federal estate and gift tax is $\$ 650,000 .{ }^{167}$

and that person's children be allowed to lose it, thereby helping to keep a society in which a person who is willing to work can get ahead whether well-born or not.

160. Bill Gates Personal Wealth Clock, (visited January 29, 1999) <http:/www.webho.com/ wealthclock>.

161. This calculation is based on an annual compounding at $8 \%$ and does not take into consideration the one-time federal estate and gift tax and generation-skipping transfer tax that will be imposed on the transfer of the Gates' wealth. See infra note 171.

162. See supra note 159 .

163. History has demonstrated that the accumulation of wealth by individuals prohibits members outside that body of wealth from being represented at many levels. The poll tax is one example of how the accumulation of wealth encroaches on one's constitutional rights. See Harper v. Virginia State Board of Elections, 383 U.S. 663 (1966) (analogizing discrimination based on wealth to that of race discrimination).

164. See supra note 159.

165. I.R.C. § 2001 .

166. There is currently a federal estate and gift tax exemption amount of $\$ 650,000$. Since 1976 , 
After the federal estate and gift tax exemption a transfer tax is imposed starting at $37 \%$ up to $55 \% .^{168}$ The GSTT penalty is an additional flat tax at the maximum estate tax rate $^{169}$ imposed on property transferred more than one generation from the settlor (skip transfer) to the extent said transfer exceeds the one million dollar GSTT exemption. ${ }^{170}$

Abolishment legislation permits a trust to remain in existence in perpetuities without regard to the Rule. Therefore settlors can skip generations indefinitely with one of two options. Transfer amounts equal to the GSTT exemption and pay no GSTT penalty or transfer property in excess of the GSTT penalty and pay the one-time penalty and avoid future transfer taxes. ${ }^{17}$ The abolishment legislation places the federal government in a position in which it imposes the only limitation on dead hand control. The wealthy settlor can transfer one million dollars without any additional transfer tax. Only transfers that exceed the GSTT exemption may be discouraged from doing so in light of the GSTT penalty. ${ }^{172}$ However, transfers in excess of the GSTT exemption remain advantageous for wealthy settlors. The transfers in excess of the GSTT exemp-

the exemption amount is represented in the Internal Revenue Code by way of a unified credit. I.R.C. $\$ 2010$. See infra note 167 . The unified credit is equivalent to the amount of tax that would be imposed on the federal estate and gift tax exemption. The generation transfer tax exemption amount is $\$ 1,000,000$. I.R.C. $\$ 2631$.

167. I.R.C. $\$ 2010$. The unified credit is a tax on the amount property is expected to increase to $\$ 650,000$ in 1999 . The schedule under $\$ 2010$ provides:

\begin{tabular}{|c|c|}
\hline 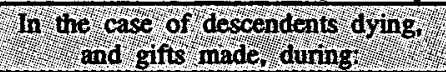 & The applicable exciusion and and ist int \\
\hline 1998 & $\$ 625,000$ \\
\hline 1999 & $\$ 650,000$ \\
\hline 2000 and 2001 & $\$ 675,000$ \\
\hline 2002 and 2003 & $\$ 700,000$ \\
\hline 2004 & $\$ 850,000$ \\
\hline 2005 & $\$ 950,000$ \\
\hline 2006 and thereafter & $\$ 1,000,000$ \\
\hline
\end{tabular}

Furthermore, by the year 2006, when the unified credit is expected to reach one million dollars, wealthy settlors will be able to transfer one million dollars into a dynasty trust without any transfer taxes.

168. I.R.C. $\$ 2001$.

169. The GSTT tax is the taxable amount multiplied by the applicable rate. I.R.C. $\$ 2602$. The applicable rate is the maximum federal estate and gift tax rate imposed on the transferor, currently $55 \%$.

170. Every transferor is allowed a $\$ 1,000,000$ exemption from the generation-skipping transfer tax $(\$ 2,000,000$ in the case of a married couple). A GSTT penalty is imposed on a skip transfer, regardless of how many generations are skipped. For example, if two million dollars were transferred from settlor to grandchild the GSTT penalty would be $\$ 550,000$ (55\% of the one million dollars that exceeded the GSTT exemption). If the two million dollars were placed in a dynasty trust, no additional GSTT penalty would be imposed even if the $\$ 1,450,000$ were left in trust to benefit future generations. This example does not take into consideration the federal estate and gift tax imposed on the transfer. I.R.C. $\$ 2001$.

171. For example, the transfer of $\$ 1,000,000$ of GSTT exempt assets invested at a growth rate of $8 \%$, compounded annually, and assuming a federal estate tax and generation-skipping tax of $50 \%$ (which was the maximum transfer tax at one time), will amount to $\$ 2,036,815,978$ after 100 years. On the other hand, the transfer of $\$ 1,000,000$ of non-exempt GSTT assets invested at the same rate of retum, with the same federal estate tax, will amount to only $\$ 254,601,997$ after the same period of time. Lawrence J. Macklin, Address at NationsBank Private Client Group Presentation (June 26, 1998). This example suggests that the penalty for this transferor is the difference between the transfer of exempt GSTT assets and non-exempt GSTT assets equaling $\$ 1,782,213,981$.

172. Id. 
tion are only subject to one federal estate tax and one GSTT penalty. Thęse transfers that continue to pass down to indefinite future generations are never subject to an additional transfer tax. Transfers may skip generations indefinitely without additional cost. $^{173}$

\section{The Abolishment Legislation Fails to provide beneficiaries with a means to terminate}

The abolishment legislation fails to mandate alternatives for termination. Trust law makes it difficult for a beneficiary to terminate a dynasty trust. ${ }^{174}$ Termination of irrevocable trusts requires all competent beneficiaries to consent to the termination. ${ }^{175}$ Termination can not be contrary to the settlor's intent and the trust purpose must be accomplished. ${ }^{176}$ Several problems arise with respect to termination of the dynasty trust. First, it will be impossible to get all the beneficiaries in interest to consent. ${ }^{177}$ Even if the beneficiaries were able to get around this requirement, ${ }^{178}$ termination will likely be contrary to the settlor's intent. At the trust's creation, the settlor's express intent was to keep the trust ongoing in perpetuity. Secondly, spendthrift provisions ${ }^{179}$ will be readily included to protect the unknown beneficiaries from the unknown creditors. ${ }^{180}$ The inclusion of a spendthrift provision will further complicate the ability of

173. Id. The present law does not place limitations on the number of generations to be skipped by the transferor. However, if the abolishment legislation is enacted readily throughout America by wealthy settlors, as a means of avoiding transfer taxes, Congress could easily impose limitations on dead hand control by limiting the number of generations that define a skip transfer. Furthermore, by the year 2006, when the unified credit is expected to reach one million dollars, wealthy settlors will be able to transfer one million dollars into a dynasty trust without any transfer taxes whatsoever.

174. Hills v. Travelers Bank \& Trust Co., 7 A.2d 652 (Conn. 1939). The case involved the termination of a trust by the then-living beneficiaries. The trust provisions provided that the property placed in trust by Mr. Hills would be distributed in the following manner: his wife, Mrs. Hills, would receive income from the trust. Upon her death and if her sons had reached the age of thirty, the principal would be divided equally among the sons. If either or both of the sons had predeceased the mother or before the sons reached the age of thirty then the trust would be distributed to the son's issue in equal shares and per stirpes. Twenty-three years after the husband's death, Mrs. Hills relinquished her "right, title and interest in the trust estate." The sons then asked the trustee to distribute the principal of the trust to them, and the trustee refused to do so.

The court sided with the trustee. The court reasoned that it does not have the authority to remake trust instruments, or to reduce or increase the size of gifts to beneficiaries because the court is restrained by the donor's intent and, therefore, can only provide to the beneficiary what the decedent wanted the beneficiary to have. In order for a trust to be terminated all interested parties must be adequately represented and agree to the trust's termination. In this instance Mr. Hills' sons had a future interest in the trust and their interests were not adequately represented since they did not have separate representation from the sons. Therefore, the court would not allow beneficiaries with a vested interest to shut out the existing or possible future interests by procuring a court decree for termination and distribution among the present holders of vested interests.

The court also viewed distribution of the trust upon the death of Mrs. Hills as a primary purpose of the trust as expressed by the decedent.

175. Id.

176. Id.

177. Dynasty trusts are generally created to provide for unbom beneficiaries. Despite the fact that some jurisdictions may permit a guardian ad litem to be appointed to represent the unborn or permit the living beneficiaries to consent, trust termination is a problem. See CAL. ProB. CODE $\$ 15405$ (West 1991); Hatch v. Riggs National Bank, 361 F.2d 559 (D.C. Cir. 1966).

178. Id.

179. The inclusion of a spendthrift provison is a per se material purpose. Culver v. Title Guarantee \& Trust Co., 70 N.E.2d 163 (N.Y. 1946).

180. In the additional-incentive jurisdiction the spendthrift provision will provide added protection from settlor's creditors and will be most definitely employed. See Sullivan, supra note 129, at 463. 
the parties to terminate. ${ }^{181}$

The abolishment legislation's failure to provide termination by the living beneficiaries in certain circumstances, regardless of settlor's initial intent and the existence of a spendthrift provision could cost the beneficiaries dearly. ${ }^{182}$ Beneficiaries may be forced to live with trust arrangements even if termination is in everyone's best interest. Furthermore, beneficiaries may be forced to expend unnecessarily on legal fees and court costs in an attempt to have a court of equity force trust termination. Moreover, the costs of defending trust litigation will deplete trust assets and beneficiaries end up paying for both sides of an up-hill battle. More often this will result in a no-win situation for the beneficiaries because the trust will not be terminated despite what is in the best interest of the beneficiaries.

In addition to the relevant concerns of dead hand control previously mentioned, other disadvantages include that the lack of contribution to social needs, debtor-creditor issues, beneficiary resentment and uninformed forum shopping.

Dynasty trusts will prohibit beneficiaries from gifting property for social needs. Property tied up in a dynasty trust will not be available for charitable purposes. ${ }^{183}$ It is unlikely that the trustee will have the ability or desire to make charitable bequests from trust assets. ${ }^{184}$ Depending on the trust's dispositive provisions, the trustee may refuse to distribute trust assets to a beneficiary to enable that beneficiary to make the charitable bequest. ${ }^{185}$ This could mean that property, an ideal candidate for a school, university, church or some other social need, would be deprived of the much-needed benefits of charitable bequests.

As previously mentioned, dynasty trusts will likely include spendthrift provisions either to protect settlors in additional-incentive jurisdictions ${ }^{186}$ or to otherwise protect beneficiaries. Limiting the beneficiary's ability to alienate trust assets causes harsh consequences for creditors. Creditors will not be able to seize trust assets. ${ }^{187}$ Beneficiaries will be equally disadvantaged and will be deprived of the ability to use property as collateral. ${ }^{188}$

Beneficiaries of a dynasty trust may resent their inheritance being restricted in a dynasty trust. Family harmony could be destroyed as a result of this resentment. ${ }^{189}$

181. See Culver, supra note 179.

182. Trust assets could be spent on unnecessary trustees' commissions.

183. Charitable trusts are exempt from the Rule. See DUKEMINIER, ProperTY, supra note 22, at 300. Abolishment of the Rule removes one of the incentives of establishing trusts with charitable beneficiaries. Thus, the wealthy settlor will be able to control property from his grave regardless of whether he or she selects charitable or private beneficiaries.

184. Trustee's fees are generally calculated as a percentage of trust assets and trust net income. See MD. CODE ANN., EsT. \& TRUSTS § 14-103 (Supp. 1998). Therefore, the trustee will have no incentive to make needed charitable gifts, which would directly result in lower trustee commissions.

185. Id.

186. See supra Part V.B.2.

187. That is for obligtions other than for necessaries, public policy concems like alimony and child support and intentional torts. Bacardi v. White, 463 So.2d 218 (Fl. 1985); Safe Deposit \& Trust Co. v. Robertson, 65 A.2d 292 (Md. 1942) (Spendthrift trust provisions should not be extended to alimony claims because the ex-spouse is a favored suitor and the claim is based upon strongest public policy grounds); Lucas v. Lucas, 365 S.W.2d 372 (Tex. 1962) (public policy will not allow a spendthrift trust beneficiary to be well taken care of when those who he has a legal duty to support must do without such support); Dillon v. Dillon, 11 N.W.2d 628 (Wis. 1943) (public policy will not prohibit spendthrift trust funds from being reached by a beneficiary's wife).

188. See DUKEMINIER, PROPERTY, supra note 22, at 226.

189. This resentment could be further complicated by a beneficiary/trustee's exercising discretionary 
Additionally, beneficiary resentment may result in litigation and additional expenses. ${ }^{190}$ Furthermore, beneficiaries may be without resources to litigate if inherited wealth is tied up in dynasty trusts.

The decision to forum shop may be based solely on the ability to create a dynasty trust without other considerations and could have detrimental affects on the beneficiaries. Unlike wills, a trust can be created in any jurisdiction. ${ }^{191}$ A settlor does not have to be domiciled in the jurisdiction in which he creates an inter vivos trust. ${ }^{192}$ Therefore settlors may attempt to minimize transfer taxes by creating an inter vivos trust in an abolishment legislation jurisdiction. Settlors may be quick to act with out weighing the disadvantages of the foreign jurisdiction. Disadvantages that may be overlooked include the consideration of where suit would be brought by or against the trustee and whether counsel will have to be retained in the abolishment legislation jurisdiction. ${ }^{193}$

In conclusion, if the abolishment legislation is not opposed, ${ }^{194}$ it will be enacted in a majority of the jurisdictions. ${ }^{195}$ The only limitation imposed on the dead hand control by these wealthy settlors is the GSTT penalty. If ever the transfer taxes were repealed $^{196}$ the dead hand would have the ability to control property without any limits whatsoever. However, the more likely consequence of the abolishment legislation trend will be for Congress to take action and close the loophole by limiting the number of generations to be skipped. ${ }^{197}$ This potential move by Congress will limit dead hand control in excess of the GSTT exemption. ${ }^{198}$

\section{Advantages of the abolishment legislation}

There is no question that the abolishment legislation offers advantages primarily benefiting the wealthy with a means by which transfer taxes can be minimized. The

decisions contrary to the wishes of another beneficiary.

190. Some examples of additional expenses included legal expenses, court costs and other costs of litigation such as discovery and hiring experts to testify.

191. Wilmington Trust Co. v. Wilmington Trust Co., supra note 88.

192. Id.

193. It is also possible that the settlor's attomey from the jurisdiction, which has not enacted the abolishment legislation, may draft the document for the abolishment legislation. This practice of law by an attorney outside the jurisdiction in which that attomey is licensed may constitute the unauthorized practice of law in the abolishment jurisdiction. This author will further explore the unauthorized practice of law, as it relates to estate planning documents in a future article.

194. By the local bar association because of the estate planning opportunities it presents or by the academic community because of their failure to be informed of the legislation as was the case with the Maryland 1998 abolishment legislation.

195. New York, for example, depends on its trust capital, has more trust capital than any other state and could not afford to lose its trust business to abolishment legislation jurisdictions. Therefore, New York may be forced to enact such legislation to remain competitive in the trust capital business. See Fraser, infra note 207.

196. Charles D. Fox, IV, Forward Into Battle: See Their Banners Go, 138 Tr. \& Est. 24 (1999); Jeffrey N. Pennell, Repeal? The Wealth Transfer Taxes?, 138 Tr. \& Est. 52 (1999); Charles D. Fox, To Repeal or Not To Repeal: Is It An Issue? Tr. \& Est., 1998 WL11601334.

197. Some scholars believe that curtailing dead hand control should not be Congress' responsibility because Congress is interested in the federal fisc, and in breaking up great fortunes and that dead hand control is likely to have a low priority in Congressional concerns. DUKEMANIER, PROPERTY, supra note 22 , at 319 .

198. This potential Congressional response to abolishment legislation will be explored in a future article. It is this author's opinion that dead hand control will not be a low priority if dynasty trusts are implemented throughout the United States so that settlors and his or her families are subject to one federal transfer tax. 
abolishment legislation clearly provides an estate planning altemative for lawyers and their wealthy clients. Additionally the abolishment legislation will provide potential trust business resulting in additional income for the abolishment jurisdiction. Furthermore, the abolishment legislation carries out the settlor's intent.

\section{Estate planning opportunities for wealthy clients}

The abolishment legislation clearly provides estate planning benefits for wealthy clients. It provides the rich with the ability to transfer wealth to future generations, retain control over trust assets and pay a one time transfer tax and possible GSTT penalty. The federal estate tax and generation skipping transfer tax advantages ${ }^{199}$ have motivated lawyers that represent wealthy clients to support the abolishment legislation. Other jurisdictions may be forced to enact the abolishment legislation as their only alternative to compete for trust business. ${ }^{200}$ Failure to give full consideration to the consequences of allowing society to be controlled by the dead will result in additional abolishment legislation being enacted. Moreover, the transfer tax advantages offered to wealthy individuals may force other jurisdictions ${ }^{201}$ to adopt the abolishment legislation.

With a dynasty trust in an abolishment jurisdiction, wealthy settlors will transfer property and such transfer will be subject to a transfer tax on the initial transfer and never again. If the transfer exceeds the exemption amounts, a federal estate and gift tax and or GSTT penalty will be imposed on the settlor or his or her estate, however, no future generations will be subject to additional transfer taxes. Trust beneficiaries will receive only a life estate in the trust assets there will be no transfer tax imposed on the trust assets at the beneficiaries' deaths. ${ }^{202}$

2. The abolishment legislation is expected to generate income for the abolishment jurisdiction

From an economic perspective the abolishment legislation generates trust business in the abolishment jurisdiction, thus, additional income may further generate additional taxes for the jurisdiction. This additional income is currently beneficial to the citizens of the abolishing state.

It is not surprising that South Dakota has enacted the abolishment legislation not only to encourage the dead hand control settlors to its state, but also to encourage new trust business within South Dakota. ${ }^{203}$ In South Dakota wealthy families are creating trust companies under the South Dakota statute. Changes in the Rule are fostering their decisions to do so. ${ }^{204}$

\section{Preservation of settlor's intent to exercise dead hand control}

The abolishment legislation honors the settlor's intent. Generally, rules of con-

199. For transfer tax explanation see supra Part V.C.3 of the text; see also Dukeminier, Dynasty Trusts, supra note 10.

200. See supra note 195.

201. Id.

202. I.R.C. $§ 2031$ (1994). With respect to the GSTT, see supra Part V.C.3, this is a 55\% penalty imposed on transfers that skip one or more generations. It is imposed on the initial skip transfer and not subsequently imposed on future generations even if the transfer skips 20 generations

203. See supra Part V.B.2.c.

204. Brigid McMenamin, Trust Yourself, Forbes, October 12, 1998, at 62. 
struction and policy concerns mandate that the settlor's intent be carried out. ${ }^{205}$ Strict adherence to the Rule departs from those rules of construction. ${ }^{206}$

The preservation of the settlor's intent is important to encourage settlors to make inter vivos gifts. If the Rule is imposed, the settlor's intent will be sacrificed and settlors will be less inclined to make inter vivos gifts without the ability to exercise dead hand control.

\section{Conclusion}

The recent trend toward abolishment legislation ignores the policy that underlies the Rule's compromise that property should be controlled by the living not the dead. Lawmakers are willing to return to dead hand control in favor of wealthy settlors minimizing transfer taxes.

Despite the fact that recent abolishment legislation requires the trustee to have the mere ability to sell trust assets or discretionary right to terminate, there is no mandatory requirement forcing the trustee to take such action. Absent an abuse of discretion, it is unlikely that the courts will intervene to require the trustee to do otherwise, even if the sale may be in the best interest of the beneficiaries.

Abolishment legislation fails to weigh the potential consequences of dead hand control. Legislators are eliminating the Rule without good reasons for doing so. In light of generous reform, abolishment is not necessary. The initial policy justifications, which were instrumental in implementing the Rule will eventually return. Marketability of trust assets will be frustrated despite the trustee's ability to sell or terminate The rich will get richer and the poor will get poorer as a result of the dead hand control perpetuating the concentration of wealth. The discouragement generated by the GSTT penalty will not be sufficient in light of the overall transfer tax advantages for the wealthy settlor. This will eventually lead to devastating results for Americans.

Abolishment legislation is now present in seven jurisdictions. Many other jurisdictions are considering abolishment legislation. ${ }^{207}$ Once the abolishment legislation trend catches on and once jurisdictions begin to loose their trust business to neighboring jurisdictions, it will create a domino effect and additional jurisdictions will be forced to abolish the rule to keep trust business with its boarders.

Before this trend progresses the legislators must recognize that the abolishment legislation permits property rights to be controlled by the dead not the living, the policy concerns that underlie the Rule's compromise should not be ignored. The sacrifice of dead hand control in exchange for another transfer tax loophole for the wealthy settlor is outrageous. State legislators should not permit dead hand control to be left to the federal government by way of the GSTT penalty.

The elimination of the Rule and allowing one to control his or her property from the grave over time will present harsh consequences. If at first glance, something sounds too good to be true, it probably is. Abolishment legislation needs to be stopped before it is too late.

205. Those rules of construction and policy considerations justify the enforcement of the spendthrift trust. Broadway Nat'l Bank v. Adams, 133 Mass. 170 (1882).

206. Some scholars believe the object of the Rule is to defeat the settlor's intent. GraY supra note 1; DUKEMINIER, PROPERTY, supra note 22, at 303.

207. Katharine Fraser, Trust-Friendly Legislation Urged for New York, AM. BANKER, February 9 , 1998 , at 8. 